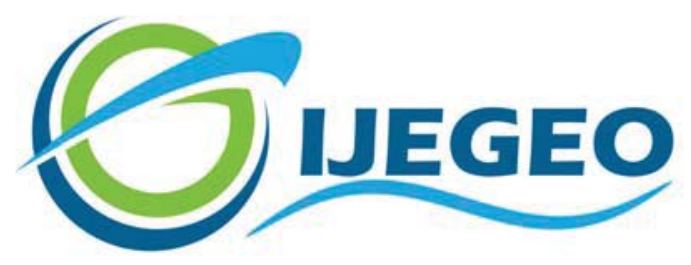

International Journal of Environment and Geoinformatics (IJEGEO) is an international, multidisciplinary, peer reviewed, open access journal.

\title{
A Preliminary Study on the Intense Pelagic and Benthic Mucilage Phenomenon Observed in the Sea of Marmara
}

\section{Neslihan BALKIS-OZDELICE, Turgay DURMUS, Muharrem BALCI}

\author{
Chief in Editor \\ Prof. Dr. Cem Gazioğlu \\ Co-Editors \\ Prof. Dr. Dursun Zafer Şeker, Prof. Dr. Şinasi Kaya, \\ Prof. Dr. Ayşegül Tanık and Assist. Prof. Dr. Volkan Demir
}

Editorial Committee (December 2021)

Assoc. Prof. Dr. Abdullah Aksu (TR), Assit. Prof. Dr. Uğur Algancı (TR), Prof. Dr. Bedri Alpar (TR), Assoc. Prof. Dr. Aslı Aslan (US), Prof. Dr. Levent Bat (TR), Prof. Dr. Paul Bates (UK), İrşad Bayırhan (TR), Prof. Dr. Bülent Bayram (TR), Prof. Dr. Luis M. Botana (ES), Prof. Dr. Nuray Çağlar (TR), Prof. Dr. Sukanta Dash (IN), Dr. Soofia T. Elias (UK), Prof. Dr. A. Evren Erginal (TR), Assoc. Prof. Dr. Cüneyt Erenoğlu (TR), Dr. Dieter Fritsch (DE), Prof. Dr. Çiğdem Göksel (TR), Prof.Dr. Lena Halounova (CZ), Prof. Dr. Manik Kalubarme (IN), Dr. Hakan Kaya (TR), Assist. Prof. Dr. Serkan Kükrer (TR), Assoc. Prof. Dr. Maged Marghany (MY), Prof. Dr. Michael Meadows (ZA), Prof. Dr. Nebiye Musaoğlu (TR), Prof. Dr. Masafumi Nakagawa (JP), Prof. Dr. Hasan Özdemir (TR), Prof. Dr. Chryssy Potsiou (GR), Prof. Dr. Erol Sarı (TR), Prof. Dr. Maria Paradiso (IT), Prof. Dr. Petros Patias (GR), Prof. Dr. Elif Sertel (TR), Prof. Dr. Nüket Sivri (TR), Prof. Dr. Füsun Balık Şanlı (TR), Prof. Dr. Uğur Şanlı (TR), Duygu Ülker (TR), Prof. Dr. Seyfettin Taş (TR), Assoc. Prof. Dr. Ömer Suat Taşkın (TR), Assist. Prof. Dr. Tuba Ünsal (TR), Dr. Manousos Valyrakis (UK), Dr. İnese Varna (LV), Dr. Petra Visser (NL), Prof. Dr. Selma Ünlü (TR), Assoc. Prof. Dr. Oral Yağcı (TR), Prof. Dr. Murat Yakar (TR), Assoc. Prof. Dr. İ. Noyan Yılmaz (AU); Assit. Prof. Dr. Sibel Zeki (TR) 


\title{
A Preliminary Study on the Intense Pelagic and Benthic Mucilage Phenomenon Observed in the Sea of Marmara
}

\author{
Neslihan Balkis-Ozdelice* iD Turgay Durmuş, iD Muharrem Balci \\ Istanbul University, Faculty of Science, Department of Biology, Division of Hydrobiology, 34134 Vezneciler-Istanbul \\ * Corresponding author: N. Balkis-Ozdelice \\ E-mail: neslbalk@istanbul.edu.tr
}

Received 20 May 2021

Accepted 08 June 2021

How to cite: Balkis-Ozdelice et al. (2021). A Preliminary Study on the Intense Pelagic and Benthic Mucilage Phenomenon Observed in the Sea of Marmara. International Journal of Environment and Geoinformatics (IJEGEO), 8(4): 414-422. doi. 10.30897/ijegeo. 954787

\begin{abstract}
In the intense mucilage formation observed in the Sea of Marmara in 2021, Phaeocystis pouchetii (Prymnesiophyceae) together with Skeletonema costatum, Cylindrotheca closterium, Thalassiosira rotula (Bacillariophyceae), and Gonyaulax fragilis (Dinophyceae) were detected in the foamy mucilage in the surface layer, and Chrysoreinhardia giraudii and Nematochrysopsis marina (Chrysophyceae), which are known to produce filamentous mucilage in benthic habitat. In addition, with the contribution of these groups, a higher cell abundance $\left(2.1 \times 10^{7}\right.$ cells/L) and chlorophyll-a value $(15.9 \mu \mathrm{g} / \mathrm{L})$ was reached than the mucilage event experienced in previous years. In the microscopic observations, typical dominant genera of the Sea of Marmara such as Protoperidinium and Tripos were observed very little in terms of species composition, and the fact that three previously unobserved species became dominant and the Cyanophyceae group was represented by different species indicated that phytoplankton composition changed in the mucilage formation in this period. The changing species composition with these three species that are known to make mucilage and which are new records for the Sea of Marmara point to the transportation by ship ballast waters or the inflow of brackish water with heavy rains. It is recommended to take the necessary measures to control domestic and industrial wastes and terrestrial inputs, which cause these species to reach numerical abundance and form mucilage, to carry out fisheries in a controlled manner, and to prevent the discharge of ship ballast waters and bilge waters.
\end{abstract}

Keywords: Mucilage, Phaeocystis pouchetii, Chrysoreinhardia giraudii, Nematochrysopsis marina, Sea of Marmara

\section{Introduction}

Mucilage is an exopolymeric organic substance that occurs in the marine environment due to the over growth of a type of sea algae, natural polymers of high molecular weight secreted by microorganisms into their environment. Extreme blooms of algae are often triggered by rising seawater temperatures and humaninduced pressures such as domestic and industrial wastes, insufficient treatment levels, excessive fishing. The Sea of Marmara is filled for months with mucilage that clogs the networks of fishers and smothers marine environment (Savun-Hekimoğlu and Gazioğlu, 2021).

The large marine aggregates and foaming formations in the Turkish Seas, especially in the Sea of Marmara, draw attention in the recent years. These formations affected fisheries in 2007-2008 and the studies have shown that some phytoplankton species (Synechococcus sp. from cyanobacteria, Cylindrotheca closterium, Pseudonitzschia sp., Thalassiosira rotula, Skeletonema costatum from diatoms, and Gonyaulax fragilis from dinoflagellates) together with bacteria played a role in it (Aktan et al., 2008; Tüfekçi et al., 2010; Balkis et al.,
2011; Balkis et al., 2013; Toklu-Alicli et al., 2020). These formations, called mucilage, are an accumulation of organic matter, which consists of protein, carbohydrates and fats, produced by various marine organisms under the special climatic and trophic conditions (Mecozzi et al., 2008).

The mucilage phenomenon, which has severe consequences on human activities such as fishing, tourism and aquaculture, have been increased in the autumn period of 2020 (as observed in previous years) and covered the surface of the entire the Sea of Marmara by spreading throughout the water column in 2021 (Figs. $1.1,1.2)$. This organic structure was much more intense and the effect was very severe than in 2007-2008. These formations are mostly white foamy on the surface (Fig. 1.3), filamentous mucous-like structures (Figs. 1.4-1.8) along the water column and at the bottom. The aim of this study is to determine the phytoplankton species that play an active role in the intense mucilage formation in the Sea of Marmara in 2021 and to make preliminary preparations for cell culture studies in order to determine the stress conditions of the species responsible for mucilage secretion. 


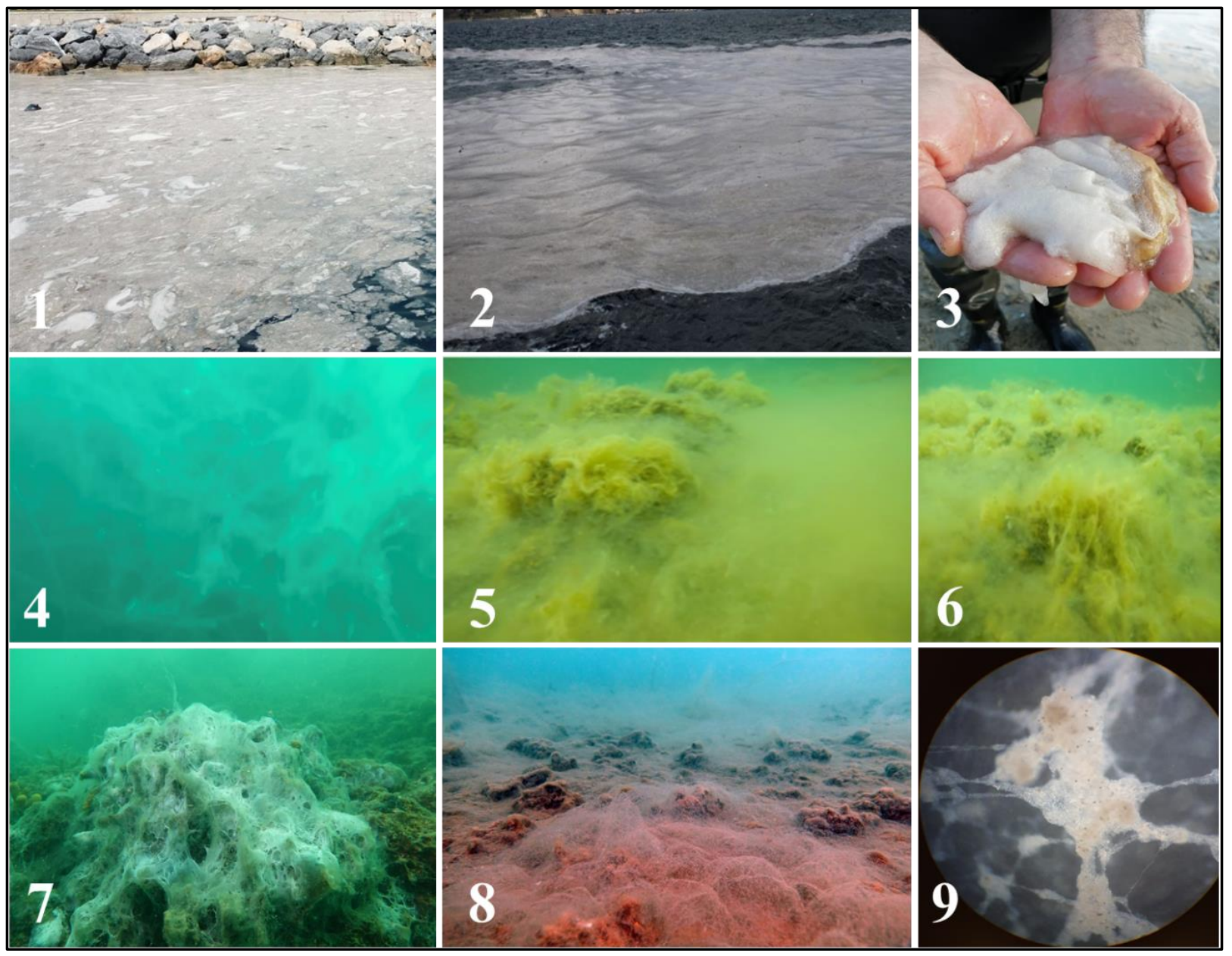

Fig. 1. 1-2) Mucilage aggregate observed on the shores of the Sea of Marmara, 3) Foamy mucilage, 4) Filamentous mucilage in the water column, 5-8) Mucilage aggregates in benthic habitat, 9) The structure of the mucilage aggregate under the light microscope (Figs.1.3, 1.7, and 1.8, Photographed by Prof. Dr. Mustafa Sarı).

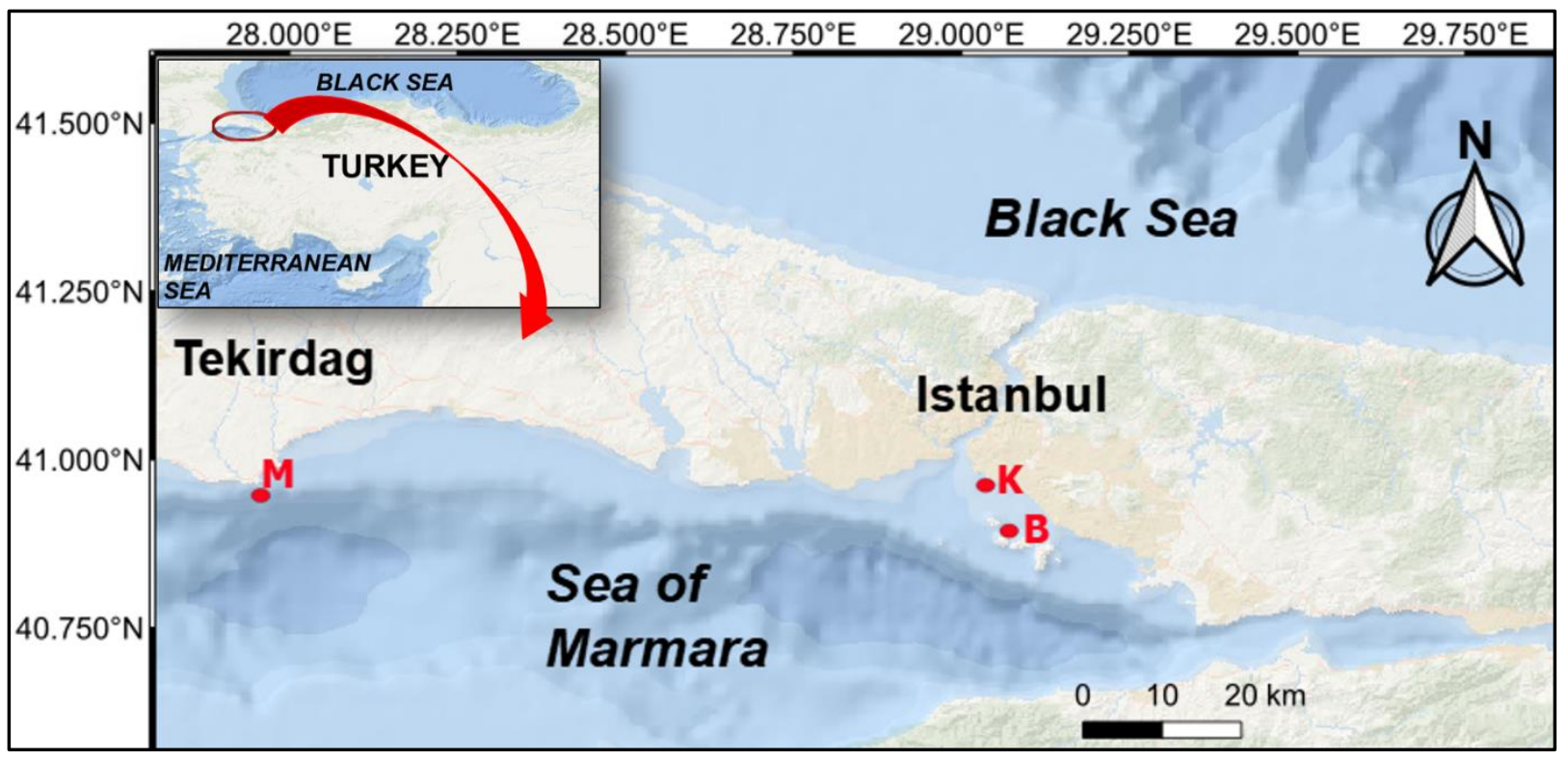

Fig. 2. Stations where mucilage samples were collected in the Sea of Marmara(B: Burgazada, K: Kadıköy, M: Marmaraereğlisi).

\section{Materials and Methods}

The samples in this preliminary study were collected from the surface at the three points in May 2021, when dense mucilage formation was observed in the Sea of Marmara (Fig. 2). The temperature anomalies in the sea surface water (L4/MUR) and chlorophyll-a values (Terra/Modis) were obtained from satellite images 
(NASA-Worldview, 2021). Phytoplanktonic organisms in the mucilage aggregates were examined in the laboratory both alive and by fixation with $4 \%$ formaldehyde buffered with borax. Olympus BX51 model light microscope was used to determine the species and to take images. In the identification and determination of phytoplankton species, the sources stated by Balk1s (2003) were used, and the cell countings were carried out in the Sedgewick-Rafter counting chamber.

\section{Results and Discussion}

A total of 47 phytoplankton species (Table 1, Figs. 3.13.49) and zooplankton belonging to eight different groups (Amoebozoa, ciliata, cladocera, copepoda, foraminifera, nematoda, nauplii larvae and veliger larvae) were detected in the mucilage aggregates (Fig. 1.9). In terms of the number of species, Bacillariophyceae was represented with 22 species (46.8\%), Dinophyceae with 16 species (34.0\%), Cyanophyceae with three species (6.4\%), Chrysophyceae and Prymnesiophyceae with two species each (4.3\%), Euglenophyceae and Dictyophyceae with one species each $(2.1 \%)$. Similar species numbers were obtained in the mucilage mass at three stations, with the detecting of highest number of species in Kadıköy (32 species), followed by Burgazada (31 species) and Marmaraereğlisi (27 species). In the microscopic investigation, the diatom species (C. closterium, Pseudonitzschia sp., $T$. rotula, and $S$. costatum) and the dinoflagellate $G$. fragilis known to be responsible for mucilage (Urbani et al., 2005) were detected in the aggregates that was observed in the same phenomenon in 2007-2008 were determined again, but also it was determined that a different nanno-planktonic haptophyte species (Phaeocystis pouchetii) and two chrysophyte species (Chrysoreinhardia giraudii and Nematochrysopsis marina) which could be also effective in this formation. All three species are new records for the Sea of Marmara. In the previous studies, it was reported that Phaeocystis pouchetii was responsible for the foamy mucilage in the surface layer (Bätje and Michaelis, 1986; Veldhuis et al., 1986), the two dominant chrysophyte species (Chrysoreinhardia giraudii and Nematochrysopsis marina) were also responsible for the benthic mucilage (Hoffmann et al., 2000). These species have been reported to present mostly in benthic habitats on macroalgae and Posidonia meadows (Hoffmann et al., 2000).

In terms of the cell abundance, the highest total phytoplankton in the mucilage aggregates were obtained in Marmaraereğlisi $\left(2.1 \times 10^{7}\right.$ cells/L), followed by Kadıköy and Burgazada $\left(9.3 \times 10^{6}\right.$ cells/L). In this study, the dominance of Bacillariophyceae and Prymnesiophyceae in terms of abundance is remarkable (Fig. 4), and Phaeocystis pouchetii was the most effective species in mucilage mass. Similarly, Bacillariophyceae and Prymnesiophyceae have been reported as dominant in the mucilage aggregate in the Northern Adriatic Sea (Flander-Putrle and Malej, 2008). Phaeocystis pouchetii reached cell abundace as $6.2 \times 10^{6}$
cells/L in Kadıköy, $4.4 \times 10^{6}$ cells/L in Marmaraereğlisi, and $2.9 \times 10^{6}$ cells $/ \mathrm{L}$ in Burgazada. Apart from this species, the most abundant species were Cylindrotheca closterium $\left(1.2 \times 10^{6}\right.$ cells/L, Burgazada), Pleurosigma sp. $\left(2.0 \times 10^{6}\right.$ cells/L, Marmaraereğlisi), Skeletonema costatum $\left(1.8 \times 10^{6}\right.$ cells/L, Marmaraereğlisi; $1.0 \times 10^{6}$ cells/L, Kadıköy), Thalassiosira rotula $\left(3.3 \times 10^{6}\right.$ cells/L), while the predominance of coccolithophorids especially in Burgazada $\left(2.4 \times 10^{6}\right.$ cells/L) and Marmaraereğlisi $\left(1.4 \times 10^{6}\right.$ cells $\left./ \mathrm{L}\right)$ is remarkable. In the previous years, Gonyaulax fragilis, which was responsible for mucilage, also reached a higher abundance in this study $\left(3.3 \times 10^{5}\right.$ cells/L, Marmaraereğlisi; $2.0 \times 10^{5}$ cells/L, Kadıköy; $8.0 \times 10^{4}$ cells/L, Burgazada) than in those years. Pseudonitzschia sp., one of the toxic species producing domoic acid, was only obtained from Kadıköy $\left(4.8 \times 10^{5}\right.$ cells/L).

Phaeocystis pouchetii, which forms mucilaginous foam, has a complex polymorphic life cycle including gelatinous colony formation (Fig. 3.42) as well as a motile solitary phase (Rousseau, et al., 1994), both of its were observed in the study flagellated cells of Phaeocystis pouchetii are spherical or oval, diameter approximately $4 \mu \mathrm{m}$, with two flagella ca $7 \mu \mathrm{m}$ in length and the alive cells are visible under light microscopy (Figs. 3.41). The cells were localized in groups in the colony. During the massive mucilage event that spread across the Sea of Marmara, Phaeocystis pouchetii played an active role, especially in the sea surface water, together with other mucilage-producing species. Such a pelagic foamy mucilage mass has also been reported from the North Sea (Lancelot, 1995). The cell isolation and culture studies have continued in order to further study the motile cell and colony of this species and to determine the stress factors. The mucilage-forming colonial form of this species was first reported from the Tasman Bay in New Zealand (Chang, 1983). According to Chang (1983), this harmful algal event was a repetition of what happened in the $1960 \mathrm{~s}$, and it was reported that in the spring of 1981, a slime-like structure in the Tasman Bay affected fishing by blocking fishing nets. The bloom of these non-motile cells was affecting the migration of herring in that area. At the same time, this slime-like structure formed large masses of 6-8 $\mathrm{m}$ in the water column (Chang, 1983). The dominant species reported from the mucilage aggregates in Tasman Bay in 1981 and those found in the mucilage mass in our study showed great similarities. Similar species are Cochlodinium sp., Gymnodinium sp., Gyrodinium sp., Oxytoxum sp. from dinoflagellates, Chaetoceros sp., Cylindrotheca closterium, Coscinodiscus sp., Pleurosigma sp., Pseudo-nitzschia sp. from diatoms and coccolithophorides. Chang (1983) observed that some species disappeared in the culture medium he created, while some species were dominant in the culture (Chaetoceros sp., C. closterium, Gymnodinium sp., Gyrodinium sp.), Phaeocystis sp. colonies were formed after 9-10 weeks, and a gel-like mass formed 4 months later. It has also been reported that Phaeocystis pouchetii is dominant in the Aegean Sea and the Black Sea, which is connected to the Sea of Marmara through the Turkish straits system, and causes mucilage (Ignatiades and Gotsis-Skretas, 2010; Petrova-Karadjova, 1990; 
Moncheva, 1991). Also, it is toxic species producing polyunsaturated aldehyde (Hansen et al., 2004). Estep et al. (1990) stated that copepods avoided grazing on healthy $P$. pouchetii colonies. In this study, copepods and other zooplankton species were negligible in seawater and mucilage samples dominated by $P$. pouchetii. In the present study, copepods and other zooplankton species were almost non-existent in the seawater and mucilage samples, which were dominated by $P$. pouchetii, PUAs may have had an effect on it. It is known that the colony of Phaeocystis has to reduce grazing pressure and this pressure on Phaeocystis colonies in the seawater is reduced compared to Phaeocystis flagellates (Hamm, 2000). It is also known that they produce PUAs (Polyunsaturated aldehydes) in $T$. rotula, $S$. costatum, which is dominant in working with this species and is responsible for mucilage. It was reported that these aldehydes inhibit cleavage of sea urchin embryos (Hansen et al., 2004).

The cells of Chrysoreinhardia giraudii (Fig. 3.39) responsible for benthic mucilage formation are spherical and approximately $14-17 \mu \mathrm{m}$ in diameter. This species was reported from Kaş (Antalya) in Turkish coastal waters (Demir, 2011). The other chrysophyte species, Nematochrysopsis marina (Fig. 3.40), is filamentous with a width of approximately $22 \mu \mathrm{m}$ and a length of 43 $\mu \mathrm{m}$. These two chrysophyte species, which are responsible for mucilage in the benthic region, have been similarly reported from the Corsica coast and have increased in mass (Hoffmann et al, 2000). The bloom species which are Phaeocystis from the North Sea and Antarctic Waters (Sieburth, 1960; Riegman et al., 1992), C. giraudii and N. marina from the Corsica coast being observed in the Sea of Marmara causing environmental problems. It can be evaluated as that ballast and bilge waters in international (overseas) ship transportation can cause negative effects by moving the species from one region to another. The mucilage in the benthic region caused by these species adversely affected the ecosystem with together the dense mucilage formation on the surface.

Seawater temperature values varied between 15.5-17.4 ${ }^{\circ} \mathrm{C}$ and the highest temperature was obtained from the sampling point of Marmaraereğlisi, while the lowest temperature was obtained from Burgazada. Considering the temperature anomalies of the sampling points, a decrease in surface water temperature was observed for the period of May 2021 (between -0.2 and $-1.0^{\circ} \mathrm{C}$ ). It is known that $P$. pouchetii, which causes foamy mucilage in surface water, releases dimethylsulfide (DMS) and acrylic acid (Sieburth, 1960; Dacey et al., 1994; Verity et al., 2006). Since the sea surface water temperature is higher than the atmosphere at night, there is heat loss by evaporation, and the atmospheric oxidation products of DMS contribute to the formation of clouds and contribute to the cooling of the atmosphere by reducing the effect of greenhouse gases (Verity et al., 2007). This may have caused surface water temperature anomalies. In terms of chlorophyll-a (chl-a) values were observed $4.0-15.9 \mu \mathrm{g} / \mathrm{L}$ from the sampling stations. In mucilage formation observed in the 2007-2008 period, chl-a values were measured between 0.10 and $6.5 \mu \mathrm{g} / \mathrm{L}$ (Balk1s et al., 2011). As can be seen, the mass increase of phytoplankton is evident in May, when mucilage is much more intense.

Cylindrotheca closterium, Skeletonema costatum, Chaetoceros sp. and Thalassiosira rotula have contributed to the both of the previous and current mucilage event in the Sea of Marmara. These species have been reported to form large-scale pelagic mucilage in the Adriatic Sea (Mingazzini and Thake, 1995), while Chaetoceros and Thalassiosira have been reported to form filamentous mucilage in nutrient-rich regions (Margalef, 1978; Sournia, 1982). The reason why diatom species are more involved in mucilage formation than dinoflagellates is that diatoms can develop and reproduce better within the mucilage aggregates (Pompei et al., 2003; Tinti et al., 2007). It should also be noted that phytoplankton communities responsible for mucilage may vary with different dominant species depending on the sampling area and period (Revelante and Gilmartin, 1991). The N/P ratio in the seawater has an impact on phytoplankton species composition and Phaeocystis was a good competitor under N-limitation than the P-limitation (Riegman et al., 1992). $\mathrm{N}$ is the limiting factor in most of the mucilage studies conducted in the Sea of Marmara, and the N/P ratio is $<16$ (Tüfekçi et al., 2010; Balk1s et al., 2011; Toklu-Alicli et al.; 2020). Colony forming Phaeocystis bloom may be restricted to those $\mathrm{N}$-controlled areas where nitrate is consumed by Phaeocystis (Riegman et al., 1992).

The mucilage substance, which is normally watersoluble, accumulated in the sea for a long time because there was not enough water current, wind and waves. Since the Sea of Marmarahas a large volume (3,378 $\mathrm{km}^{3}$ ), the hydraulic residence time of the water is long and thus the mucilage mass formed could stay in the environment for a longer time.

Diatom abundance, nutrient content of the environment, terrestrial inputs, salinity, temperature and light are effective in the rapid colonization of Phaeocystis (Kayser, 1970; Guillard and Hellebust, 1971). It is known that atmospheric precipitation plays a role in mucilage formation. The surface area of the Sea of Marmara is large (approximately $11,500 \mathrm{~km}^{2}$ ) and exposed to atmospheric precipitation (Taşdemir, 2002). Recently, the Marmara basin has been under the influence of Saharan dust and according to NASAWorldview satellite images, high chl-a values are remarkable three days after the date of 27 April 2021, when desert dust was effective. It is known that desert dust reaches its maximum level in the Eastern Mediterranean in the spring (Gullu et al., 1998) and contains aluminium $(\mathrm{Al})$, iron $(\mathrm{Fe})$, phosphorus $(\mathrm{P})$ and lead $(\mathrm{Pb})$ ions (Guieu et al., 2002). Fe ions play an important role in the nitrogen and carbon cycle (Saydam, 2014). These desert dusts may have been effective in the long stay of the mucilage in the Sea of Marmara. 
Table 1. Phytoplankton composition with cell abundances (cells/L) in the mucilage aggregates (+: Not observed in counting samples; B: Burgazada, K: Kadıköy, M: Marmaraereğlisi).

\begin{tabular}{|c|c|c|c|}
\hline TAXA & B & $\mathbf{K}$ & $\mathbf{M}$ \\
\hline \multicolumn{4}{|l|}{ Bacillariophyceae } \\
\hline Asteromphalus sp. & & & $3.3 \times 10^{5}$ \\
\hline Chaetoceros teres Cleve 1896 & + & + & \\
\hline Chaetoceros sp. & $8.0 \times 10^{4}$ & $4.0 \times 10^{5}$ & + \\
\hline Coscinodiscus lineatus Ehrenberg 1839 & $8.0 \times 10^{4}$ & + & $2.0 \times 10^{5}$ \\
\hline Cylindrotheca closterium (Ehrenberg) Reimann \& J.C.Lewin 1964 & $1.2 \times 10^{6}$ & $4.2 \times 10^{5}$ & $8.2 \times 10^{5}$ \\
\hline Ditylum brightwellii (T.West) Grunow 1885 & & & $3.3 \times 10^{5}$ \\
\hline Guinardia flaccida (Castracane) H.Peragallo 1892 & $6.0 \times 10^{4}$ & & + \\
\hline Licmophora abbreviata C.Agardh 1831 & $1.6 \times 10^{5}$ & $1.2 \times 10^{5}$ & $3.3 \times 10^{5}$ \\
\hline Licmophora flabellata (Greville) C.Agardh 1831 & $2.2 \times 10^{4}$ & $4.8 \times 10^{5}$ & $2.2 \times 10^{5}$ \\
\hline Navicula tripunctata (O.F. Müller) Bory 1822 & + & $4.8 \times 10^{5}$ & $3.3 \times 10^{5}$ \\
\hline Nitzschia sigma (Kützing) W.Smith 1853 & & + & + \\
\hline Nitzschia sp. & $2.0 \times 10^{4}$ & & + \\
\hline Pleurosigma sp. & & + & $2.0 \times 10^{6}$ \\
\hline Proboscia alata (Brightwell) Sundström 1986 & & $4.0 \times 10^{5}$ & \\
\hline Pseudosolenia calcar-avis (Schultze) Sundström 1986 & $6.0 \times 10^{4}$ & $4.0 \times 10^{4}$ & + \\
\hline Pseudo-nitzschia sp. & + & $4.8 \times 10^{5}$ & \\
\hline Skeletonema sp. & $9.6 \times 10^{5}$ & $1.0 \times 10^{6}$ & $1.8 \times 10^{6}$ \\
\hline Stephanopyxis sp. & & + & \\
\hline Striatella unipunctata (Lyngbye) C.Agardh 1832 & $6.0 \times 10^{4}$ & $6.4 \times 10^{5}$ & \\
\hline Surirella sp. & & & + \\
\hline Thalassionema nitzschioides (Grunow) Mereschkowsky 1902 & $4.0 \times 10^{4}$ & & \\
\hline Thalassiosira rotula Meunier 1910 & $1.0 \times 10^{5}$ & $2.4 \times 10^{5}$ & $3.3 \times 10^{6}$ \\
\hline \multicolumn{4}{|l|}{ Dinophyceae } \\
\hline Cochlodinium sp. & & & + \\
\hline Gonyaulax fragilis (Schütt) Kofoid 1911 & $8.0 \times 10^{4}$ & $2.0 \times 10^{5}$ & $3.3 \times 10^{5}$ \\
\hline Gymnodinium sp. & + & $1.6 \times 10^{5}$ & + \\
\hline Gyrodinium fusiforme Kofoid \& Swezy 1921 & + & + & \\
\hline Noctiluca scintillans (Macartney) Kofoid \& Swezy 1921 & & $4.0 \times 10^{4}$ & \\
\hline Oxytoxum sp. & & $3.6 \times 10^{5}$ & $6.7 \times 10^{5}$ \\
\hline Phalacroma rotundatum (Claparéde \& Lachmann) Kofoid \& J.R.Michener, 1911 & $4.0 \times 10^{4}$ & & + \\
\hline Pronoctiluca pelagica Fabre-Domergue 1889 & + & & \\
\hline Prorocentrum micans Ehrenberg 1834 & $8.0 \times 10^{4}$ & $8.0 \times 10^{4}$ & \\
\hline Prorocentrum scutellum Schröder 1900 & $2.0 \times 10^{4}$ & & $3.3 \times 10^{5}$ \\
\hline Protoperidinium bipes (Paulsen) Balech 1974 & $2.0 \times 10^{4}$ & & \\
\hline Pyrophacus sp. & & + & \\
\hline Scrippsiella acuminata (Ehrenberg) Kretschmann et al. 2015 & $2.0 \times 10^{4}$ & & \\
\hline Tripos furca (Ehrenberg) F.Gómez 2013 & $6.0 \times 10^{4}$ & & $3.3 \times 10^{5}$ \\
\hline Tripos fusus (Ehrenberg) F.Gómez 2013 & & $4.0 \times 10^{4}$ & \\
\hline Tripos muelleri Bory 1826 & & $4.0 \times 10^{4}$ & \\
\hline \multicolumn{4}{|l|}{ Chrysophyceae } \\
\hline Chrysoreinhardia giraudii (Derbès \& Solier) C.Billard 2000 & + & & \\
\hline Nematochrysopsis marina (Feldmann) Billard 2000 & & + & \\
\hline \multicolumn{4}{|l|}{ Prymnesiophyceae $=$ Haptophyceae } \\
\hline Phaeocystis pouchetii (Hariot) Lagerheim 1896 & $2.9 \times 10^{6}$ & $6.2 \times 10^{6}$ & $4.4 \times 10^{6}$ \\
\hline Coccolithophorids (Emiliania huxleyi or Coccolithus pelagicus) & $2.4 \times 10^{6}$ & $8.4 \times 10^{5}$ & $1.4 \times 10^{6}$ \\
\hline
\end{tabular}


Euglenophyceae

Eutreptiella sp.

Dictyochophyceae

Octactis speculum (Ehrenberg) F.H.Chang, J.M.Grieve \& J.E.Sutherland 2017

Cyanophyceae

Leptolyngbya lagerheimii (Gomont ex Gomont) Anagnostidis \& Komárek 1988

Pseudanabaena sp.

Scytonema sp.

\begin{tabular}{|c|c|c|c|}
\hline TOTAL NUMBER OF SPECIES & 31 & 32 & 27 \\
\hline \multicolumn{4}{|l|}{ CELL ABUNDANCES (cells/L) } \\
\hline Total Bacillariophyceae & $3.6 \times 10^{6}$ & $1.0 \times 10^{7}$ & $2.0 \times 10^{7}$ \\
\hline Total Dinophyceae & $3.2 \times 10^{5}$ & $9.2 \times 10^{5}$ & $1.7 \times 10^{6}$ \\
\hline Total Chrysophyceae & 0 & 0 & 0 \\
\hline Total Prymnesiophyceae & $5.3 \times 10^{6}$ & $7.1 \times 10^{6}$ & $5.8 \times 10^{6}$ \\
\hline Total Euglenophyceae & 0 & $8.0 \times 10^{4}$ & 0 \\
\hline Total Dictyochophyceae & $2.0 \times 10^{4}$ & 0 & 0 \\
\hline Total Cyanophyceae & 0 & 0 & 0 \\
\hline TOTAL ABUNDANCE & $9.3 \times 10^{6}$ & $1.8 \times 10^{7}$ & $2.1 \times 10^{7}$ \\
\hline
\end{tabular}

In addition, the land-based pollutants may also cause organic matter enrichment and subsequent eutrophication, since the water residence time is long in closed or semi-enclosed gulfs in the Sea of Marmara. This situation poses serious dangers for the ecosystem, especially considering the pollutants in the bioaccumulation character (Taşdemir, 2002). The contribution of heavy metals to the increasing pollution in the Sea of Marmara is significant, and excessive accumulation of copper $(\mathrm{Cu})$ in the blood of fishermen and $\mathrm{Pb}$ in mussels were determined in the measurements made (Ergül and Aksan, 2013; Çamur et al., 2021). The effects of $\mathrm{Pb}$ and $\mathrm{Cu}$ on mucilage formation have been demonstrated (Mecozzi et al., 2008). In addition, toxic pollutants such as heavy metals often come into receiving environments from industrial sources. However, the atmosphere is an important source $(\mathrm{Pb})$ in this regard (Hornbuckle et al., 1993). These toxic substances are generally carcinogenic and it has been reported that they can cause permanent disorders in the reproductive system and acute deaths (LaGrega et al., 1994; Taşdemir, 2002).

Additionally, excessive and uncontrolled fishing of filter feeder fishes such as Engraulis engrasicolus (Linnaeus,
1758), Sardina pilchardus (Walbaum, 1792) etc., which are the predators of plankton, may also be possible for these species to become dominant. Because it is known that especially intensive anchovy fishing is carried out in the Sea of Marmara (Azgider, 2016). In addition, the coastal areas with a depth of up to 30 meters, where light is effective, are very important for the survival of living communities. Most of the animals carry out feeding and breeding activities in these regions. Filling the coastal areas for various reasons disrupts the ecosystem, affects the living species, and destroys the self-cleaning feature of the seas by hitting the shore with wave movements. In the Sea of Marmara, especially in recent years, there has been intense coastal destruction. Even this situation prolonged the residence time of the mucilage mass. As a result, in order to restore the ecosystem, which has changed with the mucilage event in the Sea of Marmara, first of all, it is necessary to control domestic, industrial wastes and terrestrial inputs, fisheries and the precautions for the bilge and ballast waters. In the light of this preliminary study, it was aimed to determine the stress conditions that cause mucilage formation by culturing phytoplankton species for further experiments, to characterize the mucilage and to investigate the contribution of phytoplankton to the mucilage mass. 


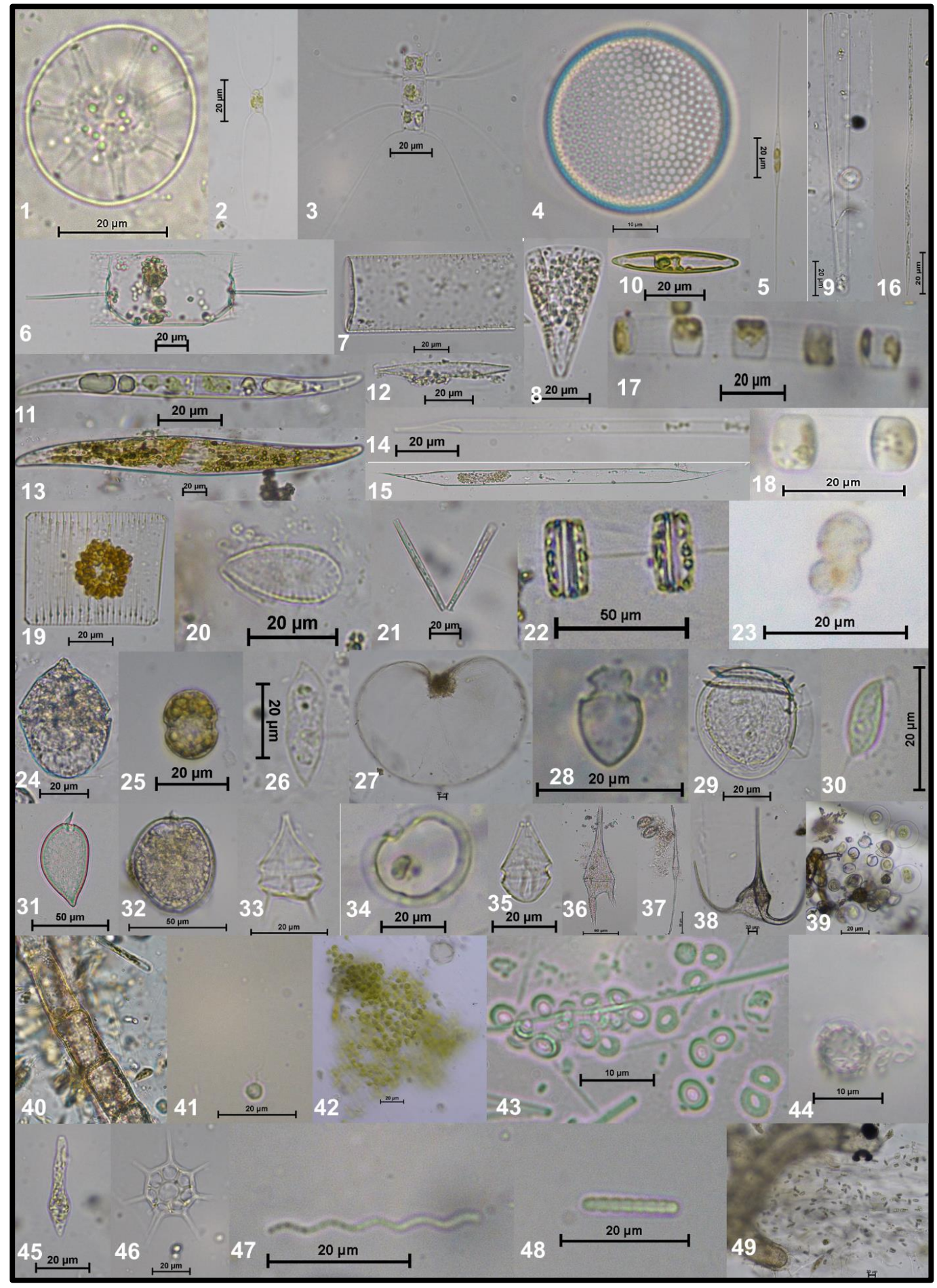

Fig. 3. The phytoplankton species in the mucilage aggregates. 1) Asteromphalus sp., 2) Chaetoceros sp., 3) Chaetoceros teres, 4) Coscinodiscus lineatus, 5) Cylindrotheca closterium, 6) Ditylum brightwellii, 7) Guinardia flaccida, 8) Licmophora abbreviata, 9) L. flabellata, 10) Navicula tripunctata, 11) Nitzschia sigma, 12) Nitzschia sp., 13) Pleurosigma sp., 14) Proboscia alata, 15) Pseudosolenia calcar-avis, 16) Pseudo-nitzschia sp., 17) Skeletonema sp., 18) Stephanopyxis sp., 19) Striatella unipunctata, 20) Surirella sp., 21) Thalassionema nitzschioides, 22) Thalassiosira rotula, 23) Cochlodinium sp., 24) Gonyaulax fragilis, 25) Gymnodinium sp., 26) Gyrodinium fusiforme, 27) Noctiluca scintillans, 28) Oxytoxum sp., 29) Phalacroma rotundatum, 30) Pronoctiluca pelagica, 31) Prorocentrum micans, 32) P. scutellum, 33) Protoperidinium bipes, 34) Pyrophacus sp., 35) Scrippsiella acuminata, 36) Tripos furca, 37) T. fusus, 38) T. muelleri, 39) Chrysoreinhardia giraudii, 40) Nematochrysopsis marina, 41-42) Phaeocystis pouchetii, 43-44) Coccolithophorids, 45) Eutreptiella sp., 46) Octactis speculum, 47) Leptolyngbya lagerheimii, 48) Pseudanabaena sp., 49) Scytonema sp. 


\section{RELATIVE ABUNDANCE}

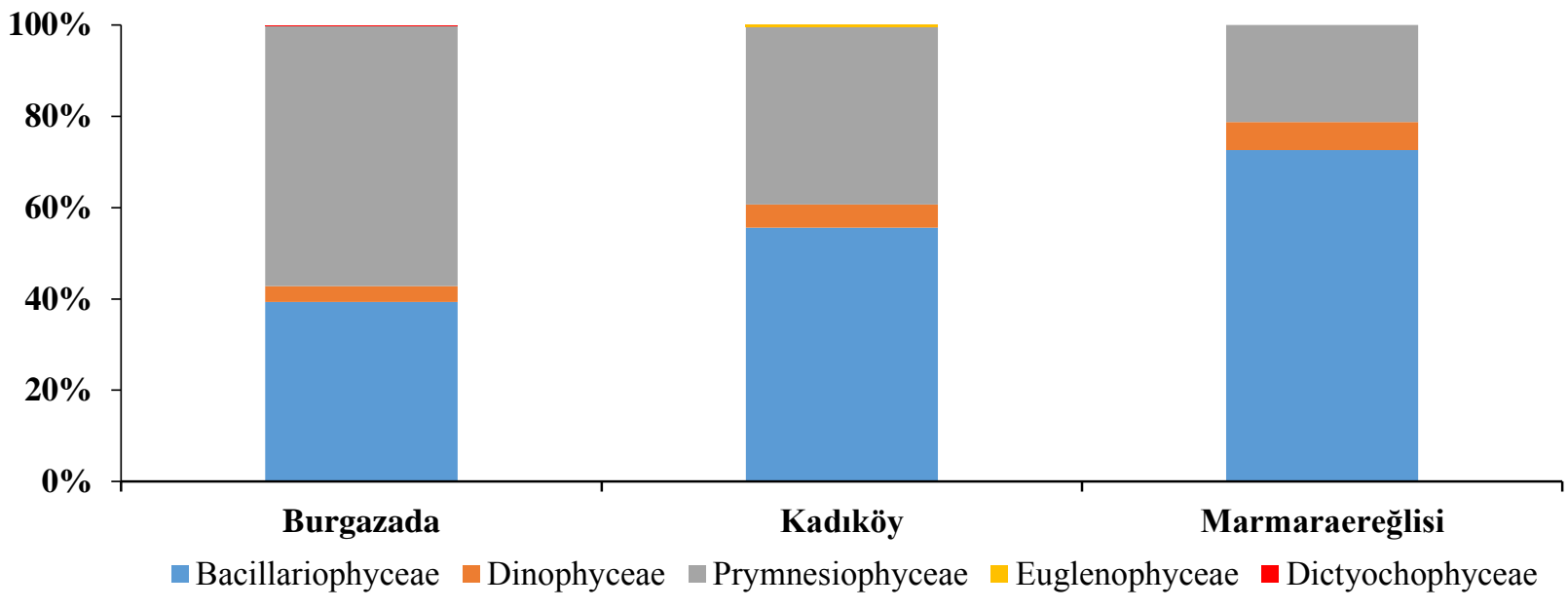

Fig. 4. Relative abundance of phytoplankton classes observed in mucilage aggregates at stations.

\section{References}

Aktan, Y., Dede A., Çiftçi P.S. (2008). Mucilage event associated with diatoms and dinoflagellates in Sea of Marmara, Turkey. An IOC Newsletter on toxic algae and algal blooms, The Intergovernmental Oceanographic Commission of UNESCO, 36, 1-3.

Azgider, B. (2016). Determination of some biological properties of the anchovy populations [Engraulis encrasicolus (Linneaus, 1758)] off Yalova in the Sea of Marmara (Marmara Denizi, Yalova açıklarında avlanan hamsi [Engraulis encrasicolus (Linneaus, 1758)] populasyonunun bazı biyolojik özelliklerinin belirlenmesi). Balıkesir University, Balıkesir, Turkey.

Balkıs N., Atabay H., Turetgen I. , Albayrak S. , Balkıs H., Tüfekçi V. (2011). Role of single-celled organisms in mucilage formation on the shores of Buyukada Island (the Sea of Marmara). Journal of the Marine Biological Association of the United Kingdom, 91, 771-781.

Balkıs, N. (2003). Seasonal variations in the phytoplankton and nutrient dynamics in the neritic water of Büyükçekmece Bay, Sea of Marmara. Journal of Plankton Research, 25, 703-717.

Balkıs, N., Sivri, N., Linda Fraim, N., Balci, M., Durmus, T., Sukatar, A. (2013). Excessive growth of Cladophora laetevirens (Dillwyn) Kutzing and enteric bacteria in mats in the Southwestern Istanbul coast, Sea of Marmara. IUFS Journal of Biology, $72(2), 41-48$.

Bätje, M., Michaelis, H. (1986). Phaeocystis pouchetii blooms in the East Frisian coastal waters (German Bight, North Sea). Marine Biology, 93(1), 21-27.

Chang, F.H. (1983). The musilage-producing Phaeocystis pouchetii (Prymnesiophyceae), cultured from the 1981 "Tasman Bay slime". New Zealand Journal of Marine and Freshwater Research, 17, 165-168.

Çamur, D., Topbaş, M., İlter, H., Albay, M., Ayoğlu, F.N., Can, M., Altın, A., Demirtaş, Y., ParlakSomuncu, B., Aydın, F., Açıkgöz, B. (2021). Heavy metals and trace elements in whole-blood samples of the fishermen in Turkey: The fish/ermen heavy metal study (FHMS). Environmental Management, 67(3), 553-562.

Dacey, J.W.H, King, G.M., Lobel, P.S. (1994). Herbivory by reef fishes and the production of dimethylsulfide and acrylic acid. Marine Ecology Progress Series, 112, 67-74.

Demir, V. (2011). Marine biological diversity assessment for marine conservation planning in Antalya-Kas using decision support systems (Kaş (Antalya) deniz koruma planlamasinda karar destek sistemleri kullanılarak biyoçeşitlilik araştırması). Istanbul University, Istanbul, Turkey.

Ergül, H.E., Aksan, S. (2013). Evaluation of nonessential element and micronutrient concentrations in seafood from the Marmara and Black Seas. Journal of Black Sea/Mediterranean Environment, 19(3), 312-331.

Estep, K.W., Nejstgaard, J.C., Skjoldal, H.R., Rey, F. (1990). Predation by copepods upon natural populations of Phaeocystis pouchetii as a function of the physiological state of the prey. Marine Ecology Progress Series, 67, 235-249.

Flander-Putrle, V., Malej, A. (2008). The evolution and phytoplankton composition of mucilaginous aggregates in the northern Adriatic Sea. Harmful Algae, 7, 752-761.

Guieu, C., Loye-Pilot, M.D., Ridame, C., Thomas, C. (2002). Chemical characterization of the Saharan dust end-member: Some biogeochemical implications for the western Mediterranean Sea. Journal of Geophysical Research, 107(15), 1-11.

Guillard, R.R.L., Hellebust, J.A. (1971). Growth and the production of extracellular substances by two strains of Phaeocystis pouchetii. Journal of Phycology, 7, 330-338.

Gullu, G.H., Olmez, I., Aygun, S., Tuncel, G., (1998). Atmospheric trace element concentration over the eastern Mediterranean Sea: Factors affecting temporal variability. Journal of Geophysical Research, 103, 21943-21954. 
Hamm, C.E., (2000). Architecture, ecology and biogeochemistry of Phaeocystis colonies. Journal of Sea Research, 43, 307-315.

Hansen, E., Ernstsen, A., Eilertsen, H.C. (2004). Isolation and characterization of a cytotoxic polyunsaturated aldehyde from the marine phytoplankter Phaeocystis pouchetii (Hariot) Lagerheim. Toxicology, 199, 207-217.

Hoffmann, L., Billard, C., Janssens, M., Leruth, M., Demoulin, V. (2000). Mass development of marine benthic Sarcinochrysidales (Chrysophyceae s.l.) in Corsica. Botanica Marina, 43, 223-231.

Hornbuckle, K.C., Achman, D.R., Eisenreich, S.J. (1993). Over-water and over-land polychlorinated biphenyls in Green Bay, Lake Michigan. Environmental Science \& Technology, 27(1), 87-98.

Ignatiades, L., Gotsis-Skretas, O. (2010). A review on toxic and harmful algae in Greek coastal waters (E. Mediterranean Sea). Toxins, 2, 1019-1037.

Kayser, H. (1970). Experimental-ecological investigations on Phaeocystis pouchetii (Haptophyceae); cultivation and waste water test. Helgolander Meeresuntersuchungen, 20, 195-212.

LaGrega, M.D., Buckingham P.L., Evans, J.C. (1994). The environmental resources management group: Hazardous waste management. Singapore: McGrawHill.

Lancelot, C. (1995). The mucilage phenomenon in the continental coastal waters of the North Sea. The Science of the Total Environment, 165, 83-102.

Margalef, R. (1978). Phytoplankton communities in upwelling area. The examples of N.W. Africa. Oecologia aquatica, 3, 97-132.

Mecozzi, M., Pietroletti, M., Conti, M.E. (2008). The complex mechanisms of marine mucilage formation by spectroscopic investigation of the structural characteristics of natural and synthetic mucilage samples. Marine Chemistry, 112(1-2), 38-52.

Mingazzini, M., Thake, B. (1995). Summary and conclusions of the workshop on marine mucilages in the Adriatic Sea and elsewhere. The Science of the Total Environment, 165, 9-14.

Moncheva, S. (1991). Eutrophication/plankton blooms/hypoxia. Presented at International Workshop on the Black Sea: Focus on the Western Black Sea Shelf, Varna, Bulgaria, 30 September- 04 October, 1991.

NASA-Worldview (2021). Retrieved May 15 ${ }^{\text {th }}, 2021$ from https://worldview.earthdata.nasa.gov

Petrova-Karadjova, V.J. (1990). Monitoring of the blooms along the Bulgarian Black Sea coast. Rapp. Comm. Int. Mer. Medit., 32(1), 209.

Pompei M., Mazziotti C., Guerrini F., Cangini M., Pigozzi S., Benzi M., Palamidesi S., Boni L., Pistocchi R. (2003). Correlation between the presence of Gonyaulax fragilis (Dinophyceae) and the mucilage phenomena of the Emilia-Romagna coast (northern Adriatic Sea). Harmful Algae, 2, 301-316.

Revelante N., Gilmartin G. (1991). The phytoplankton composition and population enrichment in gelatinous "macroaggregates" in the northern Adriatic during the summer of 1989. Journal of Experimental Marine Biology and Ecology, 146, 217-233.

Riegman, R., Noordeloos, A.A.M., Cadee, C. (1992). Phaeocystis blooms and eutrophication of the continental coastal zones of the North Sea. Marine Biology, 112, 479-484.

Rousseau, V., Vaulot, D., Casotti, R., Cariou, V., Lenz, J., Gunkel, J., Baumann, J. (1994). The life cycle of Phaeocystis (Prymnesiophyceae): Evidence and hypotheses. Journal of Marine Systems, 5(1), 23-39.

Savun-Hekimoğlu, B and Gazioğlu, C. (2021). Mucilage Problem in the Semi-Enclosed Seas: Recent outburst in the Sea of Marmara. International Journal of Environment and Geoinformatics (IJEGEO), 8(4): 402-413, doi. 10.30897/ijegeo.955739.

Saydam, A.C. (2014). Desert dust cloud interactions and natural iron enrichment mechanism. International Journal of Environment and Geoinformatics, 1(1-3), $1-11$.

Sieburth, J.M. (1960). Acrylic acid, and "antibiotic" principle in Phaeocystis in Antarctic waters. Science, 132, 676-677.

Sournia, A. (1982). Form and funtion in marine phytoplankton. Biological reviews, 57, 347-394.

Taşdemir, Y. (2002). Marmara Denizi: kirleticiler ve çevre açısından alınabilecek tedbirler. Uludağ Üniversitesi Mühendislik-Mimarlı $\quad$ Fakültesi Dergisi, 7(1), 39-45.

Tinti, F., Boni, L., Pistocchi, R., Riccardi, M., Guerrini, F. (2007). Species-specific probe, based on $18 \mathrm{~S}$ rDNA sequence, could be used for identification of the mucilage producer microalga Gonyaulax fragilis (Dinophyta). Hydrobiologia, 580, 259-263.

Toklu-Alicli, B., Polat, S., Balkıs-Ozdelice, N. (2020). Temporal variations in the abundance of picoplanktonic Synechococcus (Cyanobacteria) during a mucilage event in the Gulfs of Bandirma and Erdek. Estuarine, Coastal and Shelf Science, 233, 1-12.

Tüfekçi, V., Balkıs, N., Beken, C.P., Ediger, D., Mantıkçı, M. (2010). Phytoplankton composition and environmental conditions of a mucilage event in the Sea of Marmara. Turkish Journal of Biology, 34, 199-210.

Urbani, R., Magaletti, E., Sist, P., Cicero, A.M. (2005). Extracellular carbohydrates released by the marine diatoms Cylindrotheca closterium, Thalassiosira pseudonana and Skeletonema costatum: Effect of Pdepletion and growth status. Science of The Total Environment, 353 (1-3), 300-306.

Veldhuis, M.J.W., Colijn, F., Venekamp, L.A.H. (1986). The spring bloom of Phaeocystis pouchetii (haptophyceae) in Dutch coastal waters. Netherlands Journal of Sea Research, 20(1), 37-48.

Verity, P.G., Brussaard, C.P., Nejstgaard, J.C., van Leeuwe, M.A., Lancelot, C., Medlin, L.K. (2007). Current understanding of Phaeocystis ecology and biogeochemistry, and perspectives for future research. Biogeochemistry, 83, 311-330. 